\title{
"A STUDY TO ASSESS THE KNOWLEDGE \& PRACTICE OF STAFF NURSE REGARDING KANGAROO MOTHER CARE WITH A VIEW TO DEVELOP AN INFORMATIONAL BOOKLET IN SELECTED HOSPITALS, KOTA (RAJASTHAN)"
}

\author{
Mr. Lokesh Bhardwaj \\ Asst. Prof. Vinayak College of Nursing, Jaipur (Raj.) \\ Corresponding E-mail:-Lokeshbhrdwj751@gmail.com
}

\begin{abstract}
Introduction:- The birth of a baby is one of the most awe-inspiring and emotional events that can occur in one's lifetime. The Kangaroo Mother Care programme shows mothers how to keep their newborns warm with continuous skin-to-skin contact.

Material \& Method:-As per the Based on modified Imogene king's Goal attainment model a conceptual framework was made. The research design used was a non-experimental descriptive design; Non-Randomize Purposive sampling technique was used to select 60 subject based on certain pre determined criteria. A Structured Questionnaire Schedule was prepared for assessing knowledge and observation check list for practice of staff nurses regarding kangaroo mother care. The tool comprised of three sections.

Result:-It was evident that there was a statistically significant association between the practice score with demographic variables at the probability level of $p<0.05$.

It was evident that there was a statistically significant association between the knowledge score with demographic variables at the probability level of $\mathrm{p}<0.05$.

Conclusion: Hence the research hypothesis stated that there will be significant association between the practice score of the staff nurses with selected demographic variable was accepted. Hence the research hypothesis stated that there will be significant association between the knowledge score of the staff nurses with selected demographic variable was accepted
\end{abstract}

Key words: Knowledge, Practice, Kangaroo Mother Care

INTRODUCTION:

"Children are the wealth of tomorrow takes care of them if you wish to have a strong idea every day to meet various challenges." -Jawaharlal Nehru

The birth of a baby is one of the most awe-inspiring and emotional events that can occur in one's lifetime. After nine months of anticipation and preparation, the neonate arrives amid of flurry of excitement.
Immediately after birth, the new born make rapid adjustment to successfully adapt to life outside the womb.

The Kangaroo Mother Care programme shows mothers how to keep their newborns warm with continuous skin-to-skin contact. By keeping mother and newborn together, Kangaroo Mother Care also encourages mother and child to bond emotionally and enables the baby to breastfeed at will, giving 
the baby the energy to produce its own body heat. In many cases, the programme reduces the need for incubators, which are prohibitively expensive in developing countries.

\section{OBJECTIVES:}

$>$ To assess the knowledge of staff nurses regarding Kangaroo mother care.

$>$ To assess the practice of staff nurses regarding Kangaroo mother care.

$>$ To prepare the information booklet on Kangaroo mother care.

$>$ To find out the association between knowledge of staff nurses regarding Kangaroo mother care with selected demographic variables.

$>$ To find out the association between practice of staff nurses regarding Kangaroo mother care with selected demographic variables.

\section{HYPOTHESIS:}

$\mathbf{H}_{1}$ :- There will be statistically significant association between knowledge of staff nurses regarding Kangaroo mother care with socio demographic variables.

$\mathbf{H}_{2}$ :- There will be statistically significant association between practice of staff nurses regarding Kangaroo mother care with socio demographic variables.

MATERIAL AND METHODS:
- Research Approach:- Descriptive approach

- Research Design:- A non-experimental descriptive design selected J K LON hospital and new medical college and hospital, Kota (Rajasthan)

- Population:- The target population of the present study comprises of Staff nurses who are working and are posted in NICU, PICU, FBNC, Post-natal ward, and Child ward on rotation basis in $\mathrm{J} \mathrm{K}$ Lon Hospital and New Medical College and Hospital, Kota (Rajasthan)

- Sample :-Staff nurses who are working and are posted on rotation basis in $\mathrm{J} \mathrm{K}$ Lon Hospital and New Medical College and Hospital, Kota (Rajasthan).

- Sample Size :-60 Staff nurses who are working and are posted on rotation basis in J K Lon Hospital and New Medical College and Hospital, Kota (Rajasthan).

- Sample technique:- Non Randamize Purposive sampling technique

- Research variables ;- knowledge \& practice of staff nurses

- Demographic variables: - Age, sex, education, experience working area. 


\section{SELECTION AND}

\section{DEVELOPMENT OF THE TOOL}

The data collection technique was structured questionnaires. Structured questionnaires are considered to be the appropriate instrument to elicit the response from the samples. Keeping this in mind structured questionnaires was selected and developed on to assess the knowledge of kangaroo mother care. The tool consisted of 28 items. Observational checklist to assess practice, consist 24 items, some of the items are modified in a simplified way.

\section{SCORING CRITERIA}

Structured questionnaire Scoring criteria

- Correct response $=1$ score

- Incorrect response $=$ no( 0$)$ score

Knowledge criteria

- 0 -10 scores :- poor knowledge

- 11-19 scores :- average knowledge

- 20-28 scores :- good knowledge

Observation check list scoring criteria Yes $=1$ score No $=0$ score

Practice criteria

- 0 -08 scores :- poor practice

- 09-18 scores :- average practice

- 19-24 scores :- good practice

Intervention Package - Information booklet.

\section{The findings of study revealed} that:-
Table - 1.1: The knowledge level of Staff nurses regarding kangaroo mother care in selected hospitals, Kota, Rajasthan

\begin{tabular}{|c|c|c|}
\hline $\begin{array}{c}\text { Level of } \\
\text { Knowledge }\end{array}$ & Frequency & Percentage (\%) \\
\hline $\begin{array}{c}\text { Inadequate } \\
\text { Knowledge }\end{array}$ & 18 & 30.0 \\
\hline $\begin{array}{c}\text { Moderate } \\
\text { Knowledge }\end{array}$ & 24 & 40.0 \\
\hline $\begin{array}{c}\text { Adequate } \\
\text { Knowledge }\end{array}$ & 18 & 30.0 \\
\hline Overall & 60 & 100.0 \\
\hline
\end{tabular}

The above table 1.1, figure 1 shows the overall Level of Knowledge of staff nurses regarding kangaroo mother care. About $30 \%$ (18) of staff nurses had inadequate Knowledge, $40 \%(24)$ of staff nurses had moderate Knowledge, whereas 30\%(18) of staff nurses had Adequate Knowledge regarding kangaroo mother care at selected hospitals, kota.

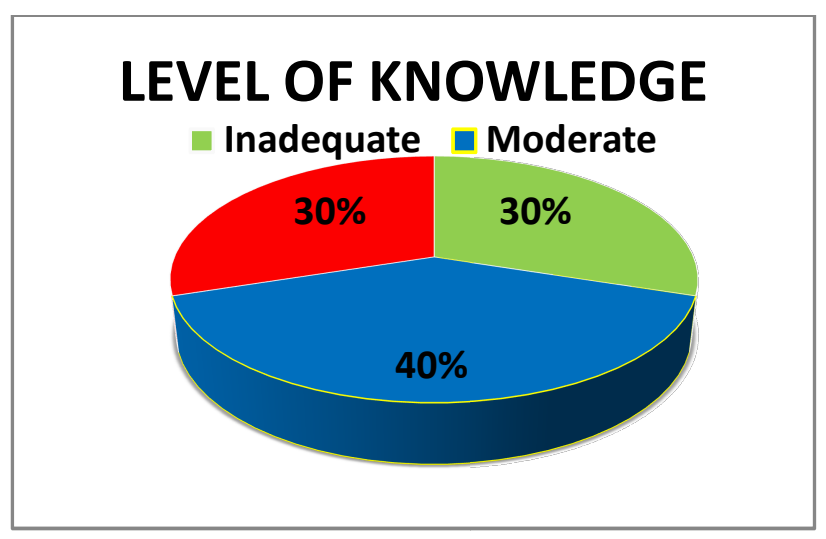

Figure 1:-PIE DIAG REPRESENTING FREQUENCY \& PERCENTAGE OF 
SUBJECT ACCORDING LEVEL OF

KNOWLEDE ON KMC

\section{Table 1.2 \\ Mean, S.D., Range, Mean score of \\ knowledge score of staff nurses \\ regarding kangaroo mother care in} selected hospital at Kota, Rajasthan

\begin{tabular}{|c|c|c|c|c|c|}
\hline \multicolumn{6}{|c|}{$N=60$} \\
\hline Aspects & $\begin{array}{l}\text { Maxi } \\
\text { mum } \\
\text { Score }\end{array}$ & Mean & SD & Range & $\begin{array}{l}\text { Mean } \\
\text { Score } \\
\%\end{array}$ \\
\hline $\begin{array}{l}\text { Question } \\
\text { related to } \\
\text { kangaroo } \\
\text { mother care }\end{array}$ & 12 & 6.32 & 2.541 & 9 & 52.66 \\
\hline $\begin{array}{l}\text { Question } \\
\text { related to } \\
\text { baby }\end{array}$ & 10 & 6.57 & 3.249 & 10 & 65.70 \\
\hline $\begin{array}{l}\text { Question } \\
\text { related to } \\
\text { mother }\end{array}$ & 6 & 3.45 & 1.943 & 6 & 57.50 \\
\hline Over all & 28 & 16.33 & 5.448 & 21 & 58.32 \\
\hline
\end{tabular}

The above table $1.2 \&$ Figure 2 shows summary of statistical outcomes of knowledge of staff nurses regarding kangaroo mother care overall maximum knowledge Score were 28. The mean score was 16.33 with standard deviation 5.448 and range from 21 . The mean score percentage was computed and it was found to be $58.32 \%$

Table - 2.1: the practice score of staff nurses of kangaroo mother care selected hospital at Kota, Rajasthan

\begin{tabular}{|c|c|c|}
\hline $\begin{array}{c}\text { Level of } \\
\text { Knowledge }\end{array}$ & Frequency & $\begin{array}{c}\text { Percentage } \\
(\mathbf{\%})\end{array}$ \\
\hline Poor practice & 14 & 23.3 \\
\hline $\begin{array}{c}\text { Average } \\
\text { practice }\end{array}$ & 34 & 56.7 \\
\hline Good practice & 12 & 20.0 \\
\hline Overall & 60 & 100.0 \\
\hline
\end{tabular}

The above table 2.1, figure 3 shows the overall Level of Practice of staff nurses regarding kangaroo mother care. About $23.3 \%$ (14) of staff nurses had Poor practice $56.7 \%$ (34) of staff nurses had Average practice, whereas $20 \%$ (12) of staff nurses had Good practice regarding kangaroo mother care at selected hospitals, Kota.

\section{FIGURE 2:- MEAN PERCENTAGE}

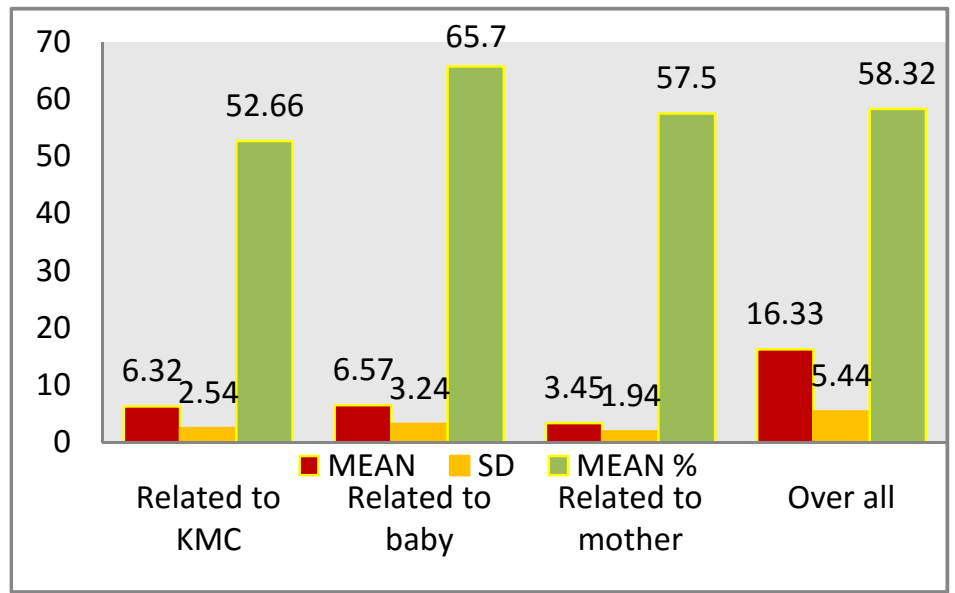

\section{FOR THE RESPONSE SCORES OF SUBJECTS REGARDING KANGAROO MOTHER CARE}



FIGURE 3:-BAR DIAG REPRESENT FREQUENCY \& PERCENTAGE OF SUBJECT ACCORDING LEVEL OF PRACTICE ON KMC 
Table 2.2 Mean, S.D., Range, Mean score\% of practice score of staff nurses regarding kangaroo mother care in selected hospital at Kota, Rajasthan

\begin{tabular}{|l|c|l|l|l|l|}
\hline Aspects & $\begin{array}{l}\text { Maxi } \\
\text { mum } \\
\text { Score }\end{array}$ & Mean & SD & Range & $\begin{array}{l}\text { Mean } \\
\text { Score \% }\end{array}$ \\
\hline $\begin{array}{l}\text { Statement } \\
\text { related to } \\
\text { kangaroo } \\
\text { mother } \\
\text { care }\end{array}$ & 8 & 3.17 & 1.278 & 7 & 39.62 \\
\hline $\begin{array}{l}\text { Statement } \\
\text { related to } \\
\text { baby }\end{array}$ & 8 & 4.13 & 1.808 & 7 & 51.62 \\
\hline $\begin{array}{l}\text { Statement } \\
\text { related to } \\
\text { mother }\end{array}$ & 8 & 6.67 & 1.258 & 4 & 83.37 \\
\hline Over all & 24 & 13.97 & 3.199 & 15 & 58.20 \\
\hline
\end{tabular}



FIGURE - 4: MEAN PERCENTAGE FOR THE RESPONSE PRACTICE SCORES OF SUBJECTS REGARDING KANGAROO MOTHER CARE.
The above table 2.2 \& Figure 4 shows summary of statistical outcomes of staff nurses regarding kangaroo mother care. Overall maximum practice Score were 24. The mean score was 13.97 with standard deviation 3.19 and range from 15. The mean score percentage was computed and it was found to be 58.20 .

Table 3.1-Association between Selected Demographic Variables and Knowledge Scores $\mathbf{N}=\mathbf{6 0}$

\begin{tabular}{|c|c|c|c|c|}
\hline Variables & df & $\chi^{\mathbf{2}}$ value & $\begin{array}{c}\text { Table } \\
\text { value }\end{array}$ & $\begin{array}{c}\text { Level of } \\
\text { significance }\end{array}$ \\
\hline Age & 2 & $\mathbf{1 5 . 3 7 9}$ & 12.591 & Significant \\
\hline Gender & 2 & $\mathbf{1 . 0 5 0}$ & $\mathbf{5 . 9 9 1}$ & $\begin{array}{c}\text { Not } \\
\text { Significant }\end{array}$ \\
\hline $\begin{array}{c}\text { Educational } \\
\text { status }\end{array}$ & 2 & $\mathbf{6 . 5 0 7}$ & 5.991 & Significant \\
\hline $\begin{array}{c}\text { Working } \\
\text { Area }\end{array}$ & 2 & $\mathbf{1 3 . 6 0 5}$ & 5.991 & Significant \\
\hline $\begin{array}{c}\text { Working } \\
\text { hours }\end{array}$ & 2 & $\mathbf{7 . 1 7 9}$ & 5.991 & Significant \\
\hline $\begin{array}{c}\text { Experience } \\
\text { in } \\
\text { pediatrics } \\
\text { wards }\end{array}$ & 6 & $\mathbf{2 3 . 7 6 9}$ & 12.591 & Significant \\
\hline $\begin{array}{c}\text { Information } \\
\text { regarding } \\
\text { Kangaroo } \\
\text { Mother } \\
\text { Care } \\
\text { gained } \\
\text { through }\end{array}$ & 6 & $\mathbf{2 0 . 1 0 7}$ & 12.591 & Significant \\
\hline $\begin{array}{c}\text { Any } \\
\text { training } \\
\text { attended }\end{array}$ & 2 & $\mathbf{1 . 7 5 1}$ & 5.991 & Significant \\
\hline
\end{tabular}

Significant $\mathrm{P}<0$.05level 
Table 3.2- Association between Selected Demographic Variables and practice Scores

$$
\mathrm{N}=60
$$

\begin{tabular}{|c|c|c|c|c|}
\hline Variables & df & $\chi^{2}$ value & $\begin{array}{c}\text { Table } \\
\text { value }\end{array}$ & $\begin{array}{c}\text { Level of } \\
\text { significance }\end{array}$ \\
\hline Age & 6 & 4.936 & 12.591 & Not Significant \\
\hline Gender & 2 & 5.500 & 5.991 & Not Significant \\
\hline $\begin{array}{c}\text { Educational } \\
\text { status }\end{array}$ & 2 & $\mathbf{6 . 8 2 1}$ & 5.991 & Significant \\
\hline $\begin{array}{c}\text { Working } \\
\text { Area }\end{array}$ & 6 & $\mathbf{1 3 . 8 7 6}$ & $\mathbf{1 2 . 5 9 1}$ & Significant \\
\hline $\begin{array}{c}\text { Working } \\
\text { hours }\end{array}$ & 2 & $\mathbf{6 . 3 9 5}$ & $\mathbf{5 . 9 9 1}$ & Significant \\
\hline $\begin{array}{c}\text { Experience } \\
\text { in } \\
\text { pediatrics } \\
\text { wards }\end{array}$ & 6 & $\mathbf{1 4 . 2 7 2}$ & $\mathbf{1 2 . 5 9 1}$ & Significant \\
\hline $\begin{array}{c}\text { Information } \\
\text { regarding } \\
\text { Kangaroo } \\
\text { Mother } \\
\text { Care gained } \\
\text { through }\end{array}$ & 6 & 5.680 & 12.591 & Not Significant \\
\hline $\begin{array}{c}\text { Any } \\
\text { training } \\
\text { attended }\end{array}$ & 2 & 1.364 & 5.991 & Not Significant \\
\hline
\end{tabular}

Significant $\mathrm{P}<0$.05level

\section{Section I: Demographic Characteristics}

Majority $41.7 \%$ of subjects belong to the each age group of 30-39 years and least $3.3 \%$ belongs to the age group of above 50 year.

Majority $66.7 \%$ of the participants were females and remaining 33.3\% were males.

Majority $90 \%$ of the participants had GNM, 10\% had B.Sc. nursing no subject have M.Sc. nursing
Among participants 35\% were posted in NICU/FBNC, $16.7 \%$ were posted in post-natal ward

Majority $63.3 \%$ of subjects are working less than 8 hours and $36.7 \%$ are working 8 hours.

Most $(36.7 \%)$ of the subjects have less than 1 year experience and least $16.7 \%$ having 3-6 years' experience.

Most $(66.7 \%)$ of the subjects gained KMC knowledge during nursing course, and least $8.3 \%$ from other sources.

Majority $91.7 \%$ of the participants not attend any training on $\mathrm{KMC}$ and $8.3 \%$ attend training.

\section{Section II: Knowledge level of staff nurses} regarding Kangaroo mother care

Majority $40 \%$ of the participants had moderate knowledge and 30\% had inadequate knowledge and 30\% had adequate knowledge regarding the kangaroo mother care.

The present study reveals that overall mean knowledge score obtained by the subjects was $16.33(46.48 \%)$ with standard deviation of 5.448 .

Section III: practice level of staff nurses regarding Kangaroo mother care

Majority $56.7 \%$ of the participants had average practice and $23.3 \%$ had poor 
practice and only $20 \%$ had good practice regarding the kangaroo mother care.

The present study reveals that overall mean practice score obtained by the subjects was $13.97(46.48 \%)$ with standard deviation of 3.199 .

Section-IV: Association between knowledge of staff nurses regarding Kangaroo mother care with selected demographic variables.

It was evident that there was a statistically significant association between the knowledge score with demographic variables like educational status, working area, experience, information regarding KMC at the probability level of $\mathrm{p}<0.05$.

Section-V: association between practice of staff nurses regarding Kangaroo mother care with selected demographic variables.

It was evident that there was a statistically significant association between the practice score with demographic variables like age, working area, working hours, experience, information regarding $\mathrm{KMC}$ at the probability level of $\mathrm{p}<0.05$. Hence the research hypothesis stated that there will be significant association between the practice score of the staff nurses with selected demographic variable was accepted.

\section{CONCLUSION}

The focus of this study was to explore the knowledge \& practice level regarding the kangaroo mother care at selected hospitals, Kota

A non-experimental descriptive design was used in the study. The data was collected from 60 samples through convenient sampling technique.

I have conducted my study on staff nurses of JK Lon Hospital and New hospital and medical college, Kota The sample size was 60 and the methodology I adopted was descriptive survey and sampling technique was purposive sampling technique.

Majority $40 \%$ of the participants had moderate knowledge and 30\% had inadequate knowledge and 30\% had adequate knowledge regarding the kangaroo mother care.

Majority $56.7 \%$ of the participants had average practice and $23.3 \%$ had poor practice and only $20 \%$ had good practice regarding the kangaroo mother care.

\section{REFERENCES:}

I. Kangaroo Mother Care A Practical

Guide. Geneva: World Health Organization; 2003 Apr: 48. Report Number: ISBN 9241590351

II. Dr. Nils Bergman. Kangaroo Mother Care: Restoring the Original Paradigm 
for Infant Care and Breastfeeding. Spring 2005 IPA Newsletter. Available fromURL:http://www.primals.org/articl es/torngren $06 . h t m l$

III. Dr Joy Lawn. Save the Children.International Journal of Epidemiology, 2010 [cited on 2010 Mar 28]. Available from URL: http://blog.babesinarms.com.au/2010/0 $\underline{4}$

IV. Marilyn J, Hockenberry. Wong's nursing Care of Infants and Children. 7th ed. Philadelphia, USA. Elsevier's publication.

V. El Taweel A, Samra $\mathrm{NM}^{1}$, Cadwell K.the effect of kangaroo mother care (KMC) on the duration of phototherapy of jaundiced neonates $\mathrm{J}$ Matern Fetal Neonatal Med. 2012 Aug;25(8):1354-7. doi: $\quad 10.3109 / 14767058.2011 .634459$. Epub 2011 Nov 28

VI. Nasheetah Solomons, C Rosant Knowledge and attitudes of nursing staff and mothers towards kangaroo mother care in the eastern sub-district of Cape Town south afreican journal of clinical nutrition vol 25 no 12012

VII. Saeidi R, Asnaashari Z, Amirnejad M, Esmaeili H,Robatsangi MR. Use of "Kangaroo Care" to alleviate the intensity of vaccination pain in newborns. Iran J Pediatr 2011 Mar; 21 (1): 99-102. Available from: URL: http://www.bioline.org.br/pdf?pe11017

VIII. Aliona Vilinsky, Ann Sheridan,Linda E. Nugent, Preventing peri-operative maternal and neonatal hypothermia after skin-to-skinconta cthttp ://dx. doi.o rg /10.1016/j.jnn.2016.02.002

IX. Kangaroo Mother Care (KMC): An Alternative to Conventional Method of Care for Low Birth Weight Babies. IJHSR. 2016; 6(3): 36-42 international journal of health science and research

X. Dalal, ArohiBala, D VChauhan, SandeepkumarMay-2014Dalal Arohi, Bala D V, Chauhan Sandeepkumar. A cross - sectional study on knowledge and attitude regarding kangaroo mother care practice among health care providers in Ahmedabad District. International Journal of Medical Science and Public Health. 2014;3(3): 253-56.

XI. Samal bhagmita, knowledge of kangaroo mother care among staff nurses, Bhubneswar, nursing times volXII no-3 June 2016 